\title{
General Methods of Management the Credit Risk
}

\author{
Constantin ANGHELACHE ${ }^{1}$, György BODÓ ${ }^{2}$ \\ ${ }^{1}$ Bucharest University of Economic Studies/„,Artifex” University of Bucharest, Romania, ${ }^{1}$ E-mail: actincon@yahoo.com \\ ${ }^{2}$ Bucharest University of Economic Studies, Romania, ${ }^{2}$ E-mail: gyorgy.bodo@yahoo.com
}

\begin{abstract}
This risks related to the lending activity is one of the most important risks that a financial-banking institution should manage. The improper or ineffective management of this kind of risks can have significant financial effect for the respective institution. Therefore, the top management has a very important role to ensure the credit risk management framework that comply both with the shareholders' expectation and also fulfil the regulatory requirement imposed by the supervisory authorities. This means need to establish proper systems, norms/procedures, and qualified staff that can assure the adequate management of the specific Credit risks. In this paper we intended to present an overview of the main elements related to the administration of credit risks that the management of financial-banking institutions should take into account. We took into account the common sources of the major credit related problems, the phases of the credit risk management, the general methods used by most of the banks in the monitoring of the credit portfolio and finally we included also strategical considerations that should be contemplated by the top management in order to properly manage the credit risk and to avoid as much as possible unexpected/unwanted situations.

Key words Credit risk, financial-banking institution, rating, credit default, non-performing loan, provisions collateral, modelling

Received: 28 Dec 2017 (C) The Authors 2018

Revised: 05 Feb 2018 Published by Human Resource Management Academic Research Society (www.hrmars.com)

Accepted: 12 Mar 2018 This article is published under the Creative Commons Attribution (CC BY 4.0) license. Anyone may Published Online: 20 Apr 2018 reproduce, distribute, translate and create derivative works of this article (for both commercial and non-commercial purposes), subject to full attribution to the original publication and authors. The full terms of this license may be seen at: http://creativecommons.org/licences/by/4.0/legalcode
\end{abstract}

\section{Introduction}

Generally speaking, the banking risk can be considered as a mix of events that can cause negative effects for the financial banking institution, and if they are not mitigated properly by the management, it might cause considerable losses for the company - either material or reputational ones.

The most important risks that have to be managed by a financial banking institution can be grouped in three main categories: Financial risks, Operational risks, and Environmental risks. The first two are linked with internal factors that the management of the company can deal with, and the last one is determined by the market conditions the respective bank operate in or it is exposed to.

The lending activity is one of the main operating areas of a commercial bank and represents the major income source for that institution. By giving loans the banks are collecting interest from customers, income that should cover the operating expenses of the company and also the expenses related to the interest paid for deposits. Therefore, the lending activity integrates also taking risks because no matter how careful they act by requesting collateral guaranties the risk of default of reimbursement of the credit as stated within the loan contract is still exist (dependent or independent of the counterparty capacity to pay).

The credit risk is part of the category of financial risks and it is associated with the current lending operation of a financial-banking institution. It refers, on the one hand, to the risk associated with nonrepayment of the loan rates by the customer at the set timeframe, but on the other hand, it is associated 
with the probability of recovering at least part of the debt related to a non-performing loan (NPL) by capitalizing the collateral in real market conditions.

Mitigating the credit risk involves the highest operational effort of a bank, which includes both the pre-credit analysis and credit monitoring activities, that has the main goal to set-up systems and procedures that enables the institution to react quickly to major events involves bank customers and to minimize the size of losses of the entire credit portfolio.

In this paper we intended to provide an overview related to the administration of credit risks that the management of financial-banking institutions should take into account. We took into account the common sources the major credit related problems, the phases of the credit risk management, the general methods used by most of the banks in the monitoring of the credit portfolio and finally we included also strategical considerations that should be contemplated by the top management in order to properly manage the credit risk and to avoid as much as possible unexpected/unwanted situations.

\section{Literature Review}

Credit risk arises from the uncertainty related to the counterparty's ability or willingness to meet its contractual obligations related to a loan. As defined by the Basel Committee on Banking Supervision, the credit risk is considered as "the potential that a bank borrower or counterparty will fail to meet its obligations in accordance with agreed terms." (BCBS, 2000)

Sfetcu (2011) and Anghel et al. (2016) addressed the general typology of risks factors related to economic activities, and presented methods for evaluating the economic activity and managing such risks. The risks faced by financial banking institutions were studied by and further investigated and summarised by Anghelache et al. (2017), where the classification of main risk factors are presented and grouped by several criteria. The credit risk is part of the financial risks category that might face by financial-banking institutions, area of interest that was largely studied and researched by Anghelache (2010) and also Apostu and Predut (2014) have a in depth analysis of their implication. Also theoretical aspects related to the banking risks were presented by Sfetcu (2008), Pirvu and Mehedintu (2010), Gavalas and Syriopoulos (2014) and also Anghelache et al. (2017) all of them presenting well structured viewpoints related to the impact of banking risks and their implications. The stages of credit risk management that covers both the decision making process, before the credit decision is made, and the follow-up of credit commitments, including all monitoring and reporting processes was assessed in detail by Miller (2014).

Cipovová and Dlasková (2016) analysed the impact of a internal rating system to the capital implication of a bank, and concluded that by using internal methodology for credit risk measurement that would bring better usage of the capital (own funds) that finally can increase the banks' performance.

The impact of transferring the credit risk to another institution was studied by Hakens and Schnabel (2010) and concluded that the banks' overall position is improved when they are able to transfer credit risk.

An important aspect relates to the role of the information in the risk management processes was studied by Anghelache, Bodó and Marinescu (2017), concluding that in the context of "information is power", more information is involved in modelling the result reflecting more accurate the reality, and underlined the trending role of big-data analysis - that in credit risk case could lead to a more accurate approval, and also monitoring processes.

Specifically, the information asymmetry between the bank and the customer was highlighted by Mishkin (2004), who considers the origin of the credit risk as a result of the adverse selection and moral hazard processes - that arises from "hidden information" between involved parties in both before the approval (analysis) and also after the credit is approved (monitoring) phases. Similarly, Anghelache and Bodó (2017) studied the impact of information asymmetry on the way how banks performing the risk management, and concluded that by using efficient IT systems and software the impact can be appropriately managed in most of the cases and also that the negative effects of information asymmetry can be kept under control.

Last but not least, the role of financial-banking supervision in Romania was deeply analysed by various norms and regulation that impact the Credit risk related activities (BNR-CNVM, 2006a), the classification of loans depending on the company performance, the loan provisioning (BNR, 2012) 
complemented by norms related to the banking supervision and prudential measures as detailed in BNR (2013) and BNR-CNVM (2006b) and other specific regulations.

\section{Research methodology and data. Results and discussions}

The credit risk is part of the financial risks category and it is originating from the various steps performed by the bank during the loan administration operations. Overall, several risk factors can be identified during the loan processing starting from the first contact with the customer and ending with the recovery of the funds given to the customer and closing the deal.

\subsection{Common sources of major credit related problems}

However, by the definition the major source of the credit risk is derived from the inability of the borrower to repay the credit, but if the bank should have taken appropriate measures, the respective credit would not been approved. Therefore, beside the customer behaviour we should identify the real rootcauses of the credit risks also within the financial-banking institution. Usually the supervisory authorities are looking for these risk elements that are linked with the banking processes and operations, and try attentively monitoring the evolution in order to avoid major disturbances in the financial markets. These sources of problems that generate credit risk were summarised in BCBS (2000) and relates to the concentrations, credit processing and monitoring, and market- and liquidity-sensitive credit exposures.

The problems related to the concentrations arises when the bank largely grant credit to business area of high risk with the mirage of the higher incomes, or expose to a single borrower (or group of companies economically interconnected) as well as sectors or industries with high similitudes (such as real estate, oil and gas etc.). Also the source of concentration can be identified by the challenge the banks facing, either to be highly specialised in a narrow area of business with very high income potential, or to be diversified in many business area (universal banks) where the competition push the prices as low as possible. We will detail later in this paper the generic ways how to avoid this kind of problems by diversifying the portfolio and setting-up limits to restrict the concentration of exposure in a single sector.

The second major problem is linked to the credit processes related issues. Many credit related problems has their origin in weaknesses of the credit approval and monitoring processes - procedures, lack of professional experience of the staff, possibilities of internal fraud (or playing the customer interest), weak supervisory activities, last but not least the decision of the management to enter in transactions with high risk potential. Therefore, the top management should pay very high attention to have elaborated detailed credit policies, procedures, and clear and independent monitoring activities organised, and invest in the education of the staff. On the other hand, the supervisory authorities are concerned of the risk management process at national level and impose rules and limits that might reduce the probability of appearance of the systemic risks.

Finally, the exposure of the market and liquidity sensitive credits affecting mainly the high value treasury related operations, where the exposure to highly volatile markets can cause problems if that market faces some disturbances. Similarly investing in financial instruments with high potential income is associated with high risk of failure, which might endanger the stability of the financial-banking institution. Therefore, before starting a new business relation with counterparties exposed liquidity sensitive markets, expanding the business in new markets or investing in financial instruments with high volatility, the bank should perform a careful analysis, and the top management should have a strategic and well documented decision and also a reaction plan put in place (plan B). By developing accurate risk management models, and by using large amount of historical and statistical data, the bank should perform periodically various stress tests in order to identify the tolerance limits to absorb such shocks.

\subsection{Stages of the credit risk management process.}

From the credit management viewpoint and interaction with the customer (that might be an individual, a commercial company or another financial institution) any lending related transaction can pass four major stages in the lifecycle.

The first stage relates to the steps performed before taking the decision of granting the loan (or making the deal). In this stage the bank make a thorough analysis of the requester also called counterparty, 
the history of past deals realised with them, the request for loan and the purpose of that will be used for, also evaluates the financial performance of the company by calculating various ratios in order to fit into various categories, the business plan that shows the financial forecasts of the business in order to ensure the capability of reimbursement in accordance with an agreed schedule, the value and quality of the collaterals etc. The analyses are made on individual basis for each requester and are completed with various eligibility criteria checking and framing into several categories. As the result of the analysis, the structures involved in the evaluation of the request either can reject the loan application as not complying with the eligibility criteria or prepare a proposal for the loan approval bodies. The specific individual steps performed in this stage can be different for each bank and it is determined by internal procedures and it is aligned with the overall risk / lending strategy of the bank.

The second stage is associated with the approval of the transaction (granting the loan) and it is performed by different structures of the bank depending on various criteria that are included in so called competency matrix. In order to diminish the risk of fraud, the decision making process is rely on at least two different level of approval, and the number of involved persons are increasing as the involved amount is larger or the deal has a high complexity or the lending period is longer. The main reason of such precaution is related to the management responsibility, that is accountable for the good operation (and profitability) of the financial-banking institution, therefore it takes all necessary steps to reduce the losses and properly manage the risks related to the lending. In any cases the decision can be framed as - granting the loan, - rejecting the proposal, or imposing additional conditions and limits that the customer have to comply (e.g. limit the loan value, requesting supplementary collaterals etc).

The third stage can be considered the longest one, and represent the close monitoring of the customer and the way of repayment of the credit and the related interests, the overall business evolution of the customer (by reassessing periodically the main business performance indicators) in order to identify any early warning signs concerned to difficulties encountered by the customer in repaying the loan. This stage is part of the credit risk monitoring process that aims to identify as soon as possible the risk factors that might expose the financial-banking institution losses and to identify modalities through which the bank take countermeasures in order to limit (diminish) the financial effect/damages. The monitoring activities can be performed at individual level or globally - grouped by various criteria in sub-portfolios, and comprehensive watching of set of prudential limits imposed by internal norms or the supervisory authorities (that will be further detailed in the next sub-section). Also, by these monitoring activities and measures taken the bank management aims to react closely to the risk events that might ultimately endanger the financial stability of the bank and to take corrective measures in a timely manner by rescheduling the loan to better fit the financial evolution of the company (increase the repayment ratio). At a higher level, also the financial supervisory bodies of each country have pay high importance to the credit risk monitoring and establish clear credit monitoring framework and various limits that might limit the overall exposure to risk of the banking system in order to avoid situation that might lead to systemic risks.

The last stage is related to the recovery actions and is applicable only to the non-preforming loans NPL (that after various attempts still have low probabilities to be repaid). This stage is the last one from the lifecycle of loans that was included into "Loss" category that the bank aims to recover as much as possible from the exposure, by using any legally allowed means. This can be made either by capitalising (selling) the collateral constituted upon the granting of the credit or by transferring a sub-portfolio of NPL to specialised companies in recovery activities. This last method was largely used by commercial banks in Romania after the crisis in order to "clean" the loan portfolio and to enhance the overall rating.

\section{Evaluating credit risk at individual level}

As we mentioned earlier, the credit related risk management activities can be performed either at individual level (for each customer and for each deal) or at consolidated - portfolio level grouped by several criteria.

The credit risk assessment at the individual level focusing on significant elements that relates primarily to the analysis of the firm's ability to pay its debt at maturity (debt service), but also $t$ the financial performance of the borrower (capital, balance sheet results, quality of guarantees, quality of management etc.). Each financial-banking institution establishes clear procedures for the assessment of the customers 
that are distinguished by categories of clients: private person, economic agent, state institution, other financial-banking institutions (in most of the cases the procedures are slightly different for each category).

The analysis process starts with eligibility checks and pre-filtering in specific databases which are available to financial-banking institutions and which could provide a high transparency and prudence on the credit applicant's history (CIP, CRC, ANAF, RECOM, courts, appeals, etc.). In addition to the applicant client, all other participants in the transaction are also reviewed, or also those who may have influence on the way the credit is performed, such as (but not limited to) shareholders owning the majority stake, co-debtors, guarantors, fiduciaries etc.

The next step relates to the assessment of the overall economic performance of the applying company, based on the specific procedures that each bank establishes by internal decisions. These procedures usually take into account the score resulted from the objective/measureable criteria based on the financial analysis of the applying company, which is then corroborated with the results of the analysis of the subjective criteria. Based on this assessment, the Romanian banking supervisory authority BNR(2013) foresee to classify the companies in 5 categories $(A, B, C, D, E)$, as follows:

Category $A$ - means very good financial performance that allows the repayment of the loan and the interest at maturity, and there are no signs of a worsening of the situation. The category B - indicates good past financial performance and on the medium/long term the level cannot be kept at similar high level but the situation can be kept under control. The category $C$ - represent satisfactory financial performance and there are indices concerning deteriorating trend. The category $\mathrm{D}$ - denotes low financial performance, and indices of certain cyclicity of business evolution in short time intervals. Finally, category $E$ - includes companies whose financial performance shows losses without signs of recovery and there are clear signs that neither rates nor interest can be paid at maturity.

On the other hand the BNR (2013) norm foresees to evaluate the Debt Service ratio and cluster it in the following three bands: GOOD - in cases where payment obligations are paid at maturity or with a maximum delay of 7 days; POOR - when there is a delay of up to 30 days in fulfilling payment obligations (even some of them are paid in due time); INADEQUATE - in situations where payment obligations are paid repeatedly with more than 30 days late.

Based on the above two criteria companies can be categorised in one of the below classes of performance (Table 1):

Table 1. Classes of performance

\begin{tabular}{|c|c|c|c|}
\hline $\begin{array}{l}\text { Debt Service } \\
\text { Performancial }\end{array}$ & GOOD & POOR & INADEQUATE \\
\hline A & Standard & Under observation & Sub-standard \\
\hline B & Under observation & Sub-standard & Doubtful \\
\hline C & Sub-standard & Doubtful & Loss \\
\hline D & Doubtful & Loss & Loss \\
\hline$E$ & Loss & Loss & Loss \\
\hline
\end{tabular}

The third step relates to the assessment of the business plan presented by the applicant, which includes the evaluation of the opportunity of the business proposal, the identification and mitigation of the risks related to the business development, the financial forecasts prepared for the very next period and also for a long term planning (usually banks requesting forecasts for the whole period of granting the loan). Additional to those presented above, the valuation of the collaterals are performed either by internal or by independent evaluators and also the past experience of the top management and the team involved in the implementation is assessed.

Based on the above assessment and if all eligibility criteria are fulfilled it will be prepared and submitted to approval a Loan Proposal, which includes mainly the following sections: the purpose of the loan and the credit limit - the maximum assumed risk/exposure; terms of the loan agreement instalments, interest rate, repayment schedule, penalties; presentation of the company past experience and financial performances; collaterals presented for securing the loan - nature, localisation, market value, 
evaluation method; loan monitoring mode - individual/portfolio level, periodicity, specific checks, KPI; special conditions, remarks, limitation, etc. The approval of the credit is taken by different decisional bodies based on the approval matrix that is specific to each credit institution - that might be at managerial level or by specific committees.

Following the approval, the monitoring can be done either at individual level for high value loans or for those granted with special conditions, respectively at a consolidated level of the sub-portfolio for low value loans and with standard conditions (grouped on various criteria of analysis). The organisational structures of the bank in charge with the loan monitoring activities periodically presents to the decision making bodies specific set of reports that contains the overview of the entire loan portfolio, framing with specific limits established by each sub-portfolio level, but also with emphasis on the performance of the high value exposures and problematic deals (NPL).

\section{Credit risk assessment at portfolio level}

In the process of managing credit risk, an important role is to track the evolution of loans grouped by certain criteria, approach that is used to avoid a significant concentration of risk associated with a particular type of business. For effective management of the credit risks at portfolio level, banks have three basic principles: Division of the loan portfolio, Limitation of the credit exposures, and Securing the credit portfolio.

The Division of the loan portfolio has the goal of spreading the credit risk among various area of business which statistically show similarities, and would not have the same incident to crisis. That means grouping the credits based on similar selection criteria such as customers' areas of activity, similar geographic regions, sectoral/economic exposure (evolving in a particular industrial sector), degree of development, etc. to show only the most important ones.

In order to limit the credit risk concentration, the banks establish a clear set of indicators in order to ensure that exposure to a particular sector does not generate significant risks for them. Thus, by the division the goal of the banks is to spread the credit risk concentration on different segments, which presents a considerable variety and that is based on the statistical component that not all problems arise at the same time (popularly said - you do not put all the eggs in a single basket). Thus, by dividing the loan portfolio, banking policies aim the dissipating the credit risk in multiple segments - one of the most accessible approaches to risk management.

The second approach, Limiting credit risk represents the limitation of exposure to a particular segment of credit, whereby the bank seeks to mitigate the impact of credit risks, as well as a limitation of exposure to a certain economic sector based on specific selection criteria. On one hand side, the limitation of exposure by sectors might be imposed by supervisory authorities, but on the other hand, depending on the assumed risk profile (risk appetite), banks are required to establish a set of indicators by which they limit themselves to exposure at a certain risk.

The National bank of Romania, as supervisory and regulatory authority, follows the consolidated global risk at national level and through regulatory interventions is aiming to limit the consolidated exposure and to avoid financial crises caused by the spread of systemic risks. Thus, the NBR norms precisely establish the limit of exposure to a single debtor or a group of companies/persons that are economically linked to each other. Respectively the EU credit risk limitation regulations contain provisions such as: a financial-banking institution cannot register an exposure to a single debtor with value exceeds $25 \%$ of its own funds; or the cumulative amount of a large exposures (exceeding $10 \%$ of the Bank's own funds) may not exceed $800 \%$ of its own funds.

A particular category of clients are the persons who are in special relationship with the bank (such as the employees, administrators + censors of the bank, majority shareholders, etc.) that need to be managed distinctly from the total loan portfolio and are processed as a special rules of analysis-approval and followup. The affiliation of special relationship is set the stage of the credit is analysed/granted and the applicant has to submit a specific statement/declaration along with the general loan application documents. The status is updated whenever changes are made in this relationship (in such case most of the banks are reanalysing entirely the conditions of the granting the loan and the collaterals involved). 
For persons in special relation with the bank, the NBR norms (BNR, 2012) force the banks to make loans approval decisions of only by the Board of Directors, based on reports and partial decisions of specialized departments. Also, the NBR norms obliges the banks to establish the "Register of loans to persons in special relations with the bank" and to keep track of their current and outstanding balances, and also to ensure that the exposure to this group of persons does not exceed $25 \%$ own funds or EUR 150 million.

Banks might establish other specific limits that are related to the lending activity - such as treasury exposures (eg stop-loss) that block a certain type of transaction when a threshold reached in order to limit the losses. The monitoring of compliance within these limits must be done within the specialized structures of the bank in order to react operatively to such events. Also, some particular limits can be obtained from various crisis scenario simulations, that might be very useful so that the bank is prepared and reacts according to established and verified scenarios (leading to a state of stability).

The last principle listed here, relates to Securing of the loan portfolio, by which the banks intend to transform the credit risk into another financial instrument (individually or at portfolio level), respectively the transfer part of the credit related risks to third party institutions that are specialised in particular narrow business areas. By such operation, banks can transfer to investors sub-portfolios of loans that will be managed globally by them, in this way the individual credit risk is diluted by statistical methods, or it is transformed into sophisticated (usually derivative) banking instruments through which the risk is transferred to these institutions - in most cases investment banks.

Another way of Securing the loan portfolio refers to the sale of loans, an operation by which the selected credits are removed from the bank's own balance sheet positions, that is also used by some banks to increase the crediting exposure. Usually the investor buys a certain sub-portfolio and the price and terms of sale are analysed globally (that includes both good and potentially bad loans). When credits are sold to third parties, the risk of default and the responsibility of the provided services are totally transferred to the buyer. A particular example is related to the portfolio of credits granted in Romania by multinational banks, which were then partly transferred to the parent banks (based on agreed selection criteria between the parties).

\section{Credit risk management and provisioning}

The evaluation of the customers' performance is made both at the moment of granting the credit to the customer, and also periodically during the entire crediting period. Therefore, the banks requesting from the customers specific documents/financial statements that proves the ability of the management of the company deals with the administration of the business, but banks can also use any alternative source of information that can provide credible details about any potential problems might be faced by the company, and that can be used to identify the any potential risk related to the credit granted to the company (reimbursement problems, shortage in cash flow etc.).

As we presented earlier, the classification of the customers are made depending on their financial performance (achieved in the past period) and the debt service (to pay the debt at maturity - for the past and forecast for the future periods), as well as the direct interaction between the customer and the bank. In order to be more precautious, the banks can perform stress tests - analysing different scenarios during that the input of the model is changed based on some hypotheses, and the output is analysed to see the direct impact. The assessment of the credit risk is performed periodically and based on the results the bank can/should take appropriate measures to mitigate the related risks.

For each credit category or interbank placement banks should set-up particular risk provisions which are correlated with the specific risk class the credit is included into. The classification are made on individual level, and the risk provisions are made up either at individual level (for large exposures) or at portfolio level based on statistical results (for small value, large number of loans). In the table below we present the rules of provisioning as stated by the NBR regulation.

It worth to mention that if the client has several loans and has difficulties in repaying a single credit (late payment), the NBR rules stipulate that all of that client's loans have to be ranked the most unfavourable category. This is called a contingency effect (contamination), case that may worsen the situation of non-performing loans if there are no appropriate measures are taken. 
Table 2. Credit categories and their description

\begin{tabular}{|c|c|c|c|}
\hline \multirow{2}{*}{$\begin{array}{c}\text { Credit } \\
\text { categories }\end{array}$} & \multicolumn{2}{|c|}{ Provisioning level } & \multirow{2}{*}{ Description/context } \\
\hline & RON & FCY & \\
\hline Standard & $0 \%$ & $7 \%$ & $\begin{array}{l}\text { There were no delays in repayment of the credit, or if the delays were } \\
\text { occasional and did not exceed } 15 \text { days (not caused by deficiencies in the } \\
\text { customer's repayment capacity) }\end{array}$ \\
\hline $\begin{array}{c}\text { Under } \\
\text { observation }\end{array}$ & $5 \%$ & $8 \%$ & $\begin{array}{l}\text { There were delays in reimbursement between } 16 \text { and } 30 \text { days, but not } \\
\text { repeatedly or consecutively (the client experienced singular deficiencies in } \\
\text { reimbursement but recovered in the short term) }\end{array}$ \\
\hline Sub-standard & $20 \%$ & $23 \%$ & $\begin{array}{l}\text { There were delays in reimbursement between } 31-60 \text { days, but not } \\
\text { repeatedly or consecutively (Customer has encountered difficulties to repay } \\
\text { the term loan, but problems seem to be seasonal, and there are clear signs } \\
\text { of recovery) }\end{array}$ \\
\hline Doubtful & $50 \%$ & $53 \%$ & $\begin{array}{l}\text { There were delays in reimbursement between } 61-90 \text { days, with some } \\
\text { repeatability (Customer often delays payment of the instalments and } \\
\text { encounters medium-term difficulties to ensure the necessary cash flow) }\end{array}$ \\
\hline Loss & $100 \%$ & $100 \%$ & $\begin{array}{l}\text { If there were repeated delays in repayment of the loan that exceeded } 90 \\
\text { days, whether it happened once or repeatedly. (The customer has severe } \\
\text { problems in assuring the medium-term / long-term cash-flow. If claims } \\
\text { recovery procedures have been initiated in court, or the company is in } \\
\text { process of legal reorganization or bankruptcy proceedings have been } \\
\text { initiated). }\end{array}$ \\
\hline
\end{tabular}

In order to protect against losses arising from credit risks (especially at high exposures levels), banks require collateral from the client - collateral, where it is important not only the type, size and value but also the speed at which they can be capitalized (turned into liquidity). The collateral/guarantees can be used for non-performing loans - NPL (with delay in reimbursement and doubtful/loss categories), so that by selling and capitalising them to be recovered as much as possible from the receivables offered by the bank and not covered by the beneficiary of the facilities.

Beside the provisioning (imposed by law) and capitalising the collateral, the banks might use also other methods such as the transfer of risks to third parties through the conclusion of insurance policies in order to cover the risk of losses on the loan portfolio. Some banks consider the outstanding claim as a loss, which were already covered from the reserve/provisions, and then try to recover as much as possible from the debtor, or simply sell the claim to specialized recovery companies. The way of acting is simple a cost benefit calculation between the effort of the recovery and the debt to be recovered.

\section{The role of the Credit policy}

The management of the financial-banking institution has very important role in framing and establishing the credit risk management strategy for the company on their double obligation, on the one hand, to shareholders to properly manage the bank's assets (without causing losses) and on the other hand, to the regulators for their compliance with the banking prudential indicators established by them (NBR, ASF etc.). The supervisory authorities, through regular reporting and controls, pursue the fulfilment of these regulatory obligations, and also observes that the commitments undertaken by the company are in correlation with the risk profile assumed, in order not to generate an exposure that may be perceived as a threat to other participants in the system (risk systemic).

Therefore, in order to limit the losses caused by the non-performing loan (NPL) portfolio, the bank's management must establish clearly formalised lending policies, implement performance-based credit risk management systems, and involve in this process staff with a perfect professional attitude and correctness. The bank should have very strict processes and procedures with that the top-management could track the evolution of the loan portfolio, in order identify the problems with promptness and to take corrective decisions so that the negative effects can be minimized. Usually, in the Romanian banks the administration of the loan portfolio is managed by specialized and independent departments, and for their supervision specific management committees are set up - such as the Risk Management Committee. In some larger 
institutions, besides the specialized departments, there are also specialized committees in the approval, administration and recovery of loans.

An impartial and useful lending policy reflects management's view of taking advantage of a market opportunity at a certain moment in time, and that have to be correlated with the risk profile assumed by shareholders, and should takes into account the following main/global objectives: to credit granting should be as secure as possible and with high reimbursement probability, and also the exposure should be covered with additional solid and liquid guarantees; to place the available funds as safe as possible within secure financial instruments given the optimal level of income and assumed risks; to focus mainly on loans that are in economic need of the market (demand and supply), and for which the bank has specific differentiation factors.

In practice, banks approve and grant to customers only those credits that integrate into the portfolio's risk structure. The aim is to include in the portfolio only those loans that correspond to the Bank's strategy and policies and which can be evaluated in terms of risk. The credit risks can be managed by limiting individual exposure and by consolidation, being possible to manage the portfolio in the context of establishing expected costs in relation to the risks assumed.

Therefore the credit risk must be measured, controlled, monitored and managed at both individual and portfolio levels, by keeping permanently linked the risk of individual credit with the overall risk of the entire portfolio. It can be considered as two risks are positively correlated if they increase or decrease synchronously as a result of changing risk factors and are negatively correlated if one decreases when the other increases and vice versa. This means that determining such a correlation is of great importance in measuring and managing the overall credit risk, and are elementary components in constructing risk models and decision making structures.

Credit policies shall be reviewed periodically and adjusted to the economic conditions specific to the market in which that financial banking institution operates, in order to be able to respond quickly to internal/external events that can be considered as threats. It is a continuous process of learning from experience and adapting to the ever changing business environment, therefore a strategy can be considered as suitable in a certain moment in time and within a certain specific business condition.

\section{Conclusions}

Crediting activity is associated with a set of specific risks that management of financial and banking institutions must take into account in order to avoid any kind of losses. Moreover, by properly managing the assumed risks, the losses from the lending portfolio can be minimized if the institution has adequate monitoring tools (systems and staff) and also appropriate regulatory framework that allows the management to take quick reaction to threats, and to prevent triggering chain-events that may have disastrous effects on the institution.

Any credit granted to customers is in fact an anticipation of future receipts/incomes, and they involve the risk that the income will be delayed and will not be realized at the expected time or in worst case will not be realised at all. Thus, a fair approach to credit risk policy is that a credit is granted only on condition that the probability of repayment is greater than the probability of default, in the context of the risk profile assumed by the management.

The first conclusion of this study, is that financial-banking institutions should have clear strategy and specific policies/procedures to properly manage the credit risks. The top-management is solely responsible for the actions taken in order to minimize the losses related to non-performing loans (NPL). In any stages of the credit lifecycle it should be put in place efficient monitoring and modelling tools that should assist the management to take the most appropriate decision as reaction to an internal/external threat.

Secondly, the credit risks can be identified, can be measured and correlated between various factors. Well-structured credit risk management models can help in the decision making process at the approval stage, but also later, after the approval by the closely monitoring of the evolution of the reimbursement and business environment evolution, the risk can be controlled, diminished or most likely eliminated.

Finally, the exchange of information between the customer and the bank is the basis of trust between the parties, and the more clear, reliable and transparent the information is, that can lead to a more accurate assessment of the situation of the credit. On the other hand, obtaining information from 
independent, trustworthy sources is an suplementary element for the efficient management of credit risk. The higher amount of available information (big-data), and the reliability of the sources, could reduce the differences in perception between customer and bank viewpoint and the risks can be anticipated with greater accuracy.

\section{References}

1. Anghel M., Diaconu A., and Popovici M. (2016). Theoretical considerations regarding risk analysis models, Romanian Statistical Review - Supplement, 9, 64-72.

2. Anghelache, C. (2006). Elemente privind managementul financiar, Note de curs, Editura Artifex, Bucuresti.

3. Anghelache, C. (2010). Metode și modele de măsurare a riscurilor si performanțelor finaniarbancare, ediția a doua, Editura Artifex, Bucuresti.

4. Anghelache, C., Anghel, M.G. and Bodó, G. (2017a). Theoretical aspects of the role of information in the process of decisions/risks modeling. Romanian Statistical Review - Supplement, 6, 102-111.

5. Anghelache C., Bodó G. and Marinescu A. I. (2017b). Asymmetric Information in Case of Decision under Risk, Romanian Statistical Review - Supplement, 1, 22-36.

6. Anghelache, C., Sfetcu M., Bodó, G., and Avram D. (2017) Theoretical notions about banking risks. Romanian Statistical Review - Supplement, 11, 33-42.

7. Apostu, T., Predut, A. S. (2014), - Riscul de credit, Colecţia de working papers ABC-UL lumii financiare, 2, 186-207.

8. Cipovová, E. and Dlasková, G. (2016). Comparison of Different Methods of Credit Risk Management of the Commercial Bank to Accelerate Lending Activities for SME Segment, European Research Studies, 19(4), 17-26.

9. Echart, L, Gollier, C, Schlesinger, H, (2005). Economic and Financial Decisions under Risk, Princeton University Press.

10.Gavalas D. and Syriopoulos T. (2014) Bank Credit Risk Management and Rating Migration Analysis on the Business Cycle, International Journal of Financial Studies, 2(1), pp. 122-143.

11.Miller P. G. (2014). The Role of Risk Management and Compliance in Banking Integration, New York University Law and Economics Working Paper, 2014-11, 1-26.

12.Mishkin, S. F. (2004). The Economics of Money, Banking and Financial Markets, Columbia University, $7^{\text {th }}$ edition, 2004, Chapter 9.

13.Pîrvu, C., Mehedinţu, A. (2010) Considerations Concerning the Banking Credit and its Optimization", Annals of the University of Petroşani - Economics, nr. 4/2010.

14.Sfetcu, M. (2008) Lending Risk - The quality function of banking loan portfolio, Romanian Statistical Review - Supplement, vol. 2008, nr. 10, 29-48.

15.Sfetcu, M. (2011) Indicatori de evaluare a situațiilor financiare ale clienților gestiunii resurselor, Romanian Statistical Review - Supplement, trim III, 82-89.

16.BCBS (2000). Principles for the Management of Credit Risk, Basel Committee on Banking Supervision - Basel, September 2000.

17.BNR (2012). Regulament nr. 5/2012, privind clasificarea creditelor şi constituirea, regularizarea şi utilizarea provizioanelor specifice de risc de credit aplicabil entităţilor supravegheate de Banca Naţională a României, altele decât instituţiile de credit, published in The Official Gazette of Romania, Part I 179 20.mar.2012.

18.BNR (2013). Regulament nr. 5/2013 privind cerinţe prudenţiale pentru instituţiile de credit, published in The Official Gazette of Romania, Part I 841 30.dec.2013.

19.BNR-CNVM (2006a). Regulamentul BNR - CNVM nr.14/19/2006 privind tratamentul riscului de credit pentru instituţiile de credit şi firmele de investiţii potrivit abordării standard.

20.BNR-CNVM (2006b). Regulamentului BNR - CNVM nr.17/22/2006 privind supravegherea pe bază consolidată a instituţiilor de credit şi a firmelor de investiţii. 